\title{
DETERMINATION OF PHYTOCOMPONENTS IN ETHANOL EXTRACT OF BRASSICA OLERACEA - USING GAS CHROMATOGRAPHY-MASS SPECTROSCOPY TECHNIQUE
}

\author{
JAYALAKSHMI M, VANITHA V*, SANGEETHA R \\ Department of Biochemistry, School of Life Sciences, Vels Institute of Science, Technology and Advanced Studies, Pallavaram, \\ Chennai-600 117, Tamilnadu, India. Email: vanitha.sls@velsuniv.ac.in
}

Received: 31 May 2018, Revised and Accepted: 08 June 2018

\section{ABSTRACT}

Objectives: Bioactive components determined by plants are known to have a broad application in the medical field. The focus of this study is to recognize the phytochemicals in the ethanol extract of Brassica oleracea by gas chromatography-mass spectroscopy (GC-MS).

Methods: B. oleracea was collected, dried, and powdered well. The extraction was done with the solvent ethanol. The extract was exposed to column of GC-MS-QP 2010 (SHIMADZU) column Db 30.0 (0.25 $\mu \mathrm{m}$ in diameter, $0.25 \mu \mathrm{m}$ thick).

Results: GC-MS result provides the chromatogram with different peaks obtained at a different retention time shows the presence of various biocompounds. Some of the identified bioactive compounds are n-hexadecanoic acid (12.99\%), phytol (2.40\%), Vitamin E (3.38\%), tetratetracontane (2.15\%), stigmasterol (2.03\%), and isophytol.

Conclusion: The GC-MS study of the ethanol extract of B. oleracea reveals the existence of many potential compounds that can be utilized in the pharmaceutical industry, including the use of anti-inflammatory, antiarthritic, anticoronary, and antidiabetic agents.

Keywords: Brassica oleracea, Gas chromatography-mass spectroscopy, Tetratetracontane, Stigmasterol, Phytocompounds, antioxidant.

(C) 2018 The Authors. Published by Innovare Academic Sciences Pvt Ltd. This is an open access article under the CC BY license (http://creativecommons. org/licenses/by/4. 0/) DOI: http://dx.doi.org/10.22159/ajpcr.2018.v11i10.26857

\section{INTRODUCTION}

Plant sources play a substantial role in the drug development industry. The developing countries are recommended to use ancient way of herbal medicines by the World Health Organization to treat the various chronic illnesses [1]. In India, accustomed systems of medical treatment such as Unani, Ayurveda, and Siddha are established on the herbal drugs [2]. The active biocomponents of the therapeutically valued plants are expansively used in treating the mild or chronic disorders [3]. In plants, every portion of the bark, leaves, flowers, roots, seeds, and fruit is acting as the sources for the biologically active biocompounds [4].

Nowadays, researchers have diversified their scrutiny toward the herbal side for the finding of new drugs because of the less toxicity and cost-effective. Many of the compounds demonstrate a foremost role as metallic enzymes and as enzyme cofactors [5,6]. Brassica oleracea is a pharmaceutical valued plant which comes under the botanical family Cruciferae. Broccoli features are look-alike cauliflower, and it is highly valuable and desirable food among the Italians [7]. Broccoli is the remarkable healthy diet item which is well off in protein, beta-carotene, Vitamin C, Vitamin B6, potassium, and calcium, and they are high in fiber [8].

Broccoli is enriched with the plenty of metabolites such as flavonoids, glucosinolates, glucoraphanin, glucoiberin, and sulforaphane. These constituents of broccoli show that Broccoli exhibits high therapeutic properties and are used in curing various chronic diseases. Broccoli is found to play a significant part in the treatment of arthritis. Broccoli is also tangled in the maintaining the insulin level and plays an extensive role in treating the kidney diseases [9].

Gas chromatography-mass spectroscopy (GC-MS) is the finest method to scrutinize the biologically active constituents, namely alcohols, longchain hydrocarbons, branched chain hydrocarbons, esters, etc. GC is the preferable tool on account of its sensitivity, effective in separating the constituents from the mixture and also used for the qualitative and quantitative study of the mixture. By GC-MS, we can also record a mass spectrum of each component [10]. Hence, this paper is focused on the detection of biocompounds present in broccoli by GC-MS analysis and to assess its pharmacological properties.

\section{METHODS}

\section{Collection of the plant material}

The edible parts of $B$. oleracea were collected from the local marketplace and it was washed well. The edible parts were cut into a small piece and shade dried for about 7 days. The dried parts were powdered well, which further got into extraction process.

\section{Authentication of the plant material}

The plant material B. oleracea was collected and authenticated in ICAR by Dr. N. Kaliaperumal M.Sc., Ph.D., Scientist-in-charge, CMFRI.

\section{Preparation of the plant extract}

The sample powder was extracted using $99.8 \%$ ethanol solvent. The sample was submerged in ethanol and it was incubated for $72 \mathrm{~h}$ inside an incubator. After the incubation period, it was filtered using a muslin cloth, and the filtrate was kept open in the closed space for the ethanol to evaporate completely. The remains of the filtrate were the crude ethanol extract of broccoli, which was maintained at $4^{\circ} \mathrm{C}$ for analytical purposes.

\section{GC-MS}

GC-MS technique was performed to analyze the phytocomponents exist in the ethanol extract of Broccoli. This technical process was done in the SMS Laboratory, Thiruvallur, Tamil Nadu. Chromatographic separation was performed using a column of GC-MS-QP 2010 (SHIMADZU) column $\mathrm{Db} 30.0(0.25 \mu \mathrm{m}$ in diameter, $0.25 \mu \mathrm{m}$ thick $)$. The oven temperature is raised to $10^{\circ} \mathrm{C} / \mathrm{min}$ to $200^{\circ} \mathrm{C}$ and then programmed to $5^{\circ} \mathrm{C} / \mathrm{min}$ to $280^{\circ} \mathrm{C}$ and $70^{\circ} \mathrm{C}$ (isothermal $5 \mathrm{~min}$ ) ending to $35^{\circ}$ isothermal. Obtained at 70 


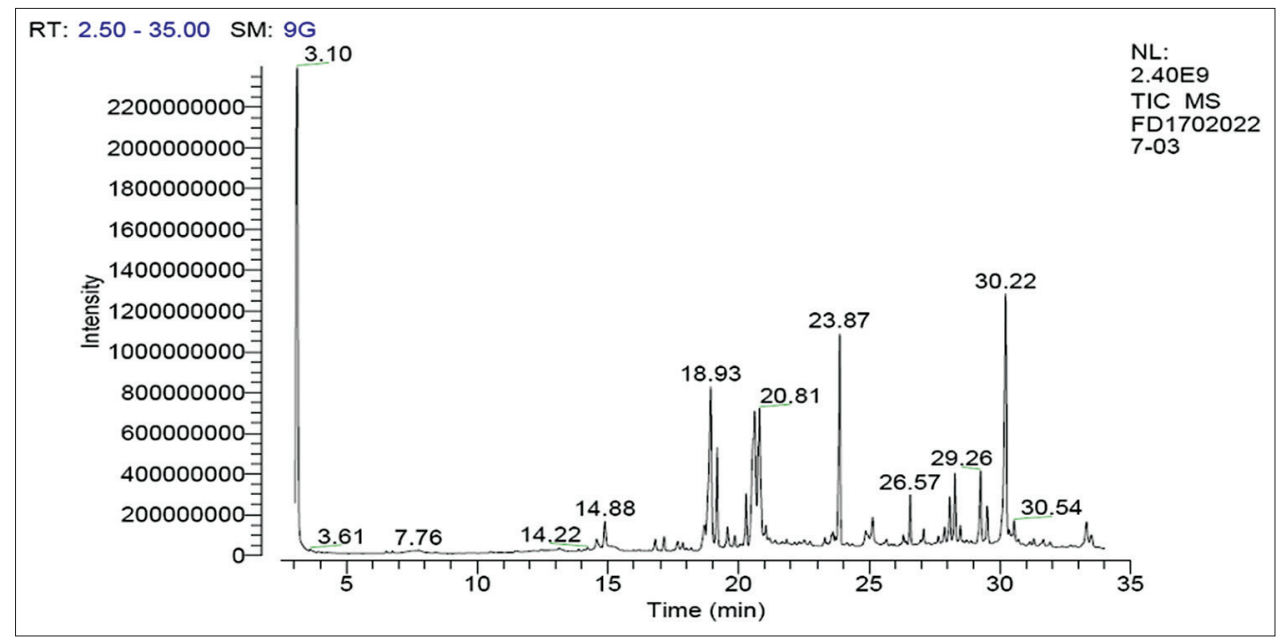

Fig. 1: Chromatogram of ethanol extract of Brassica oleracea
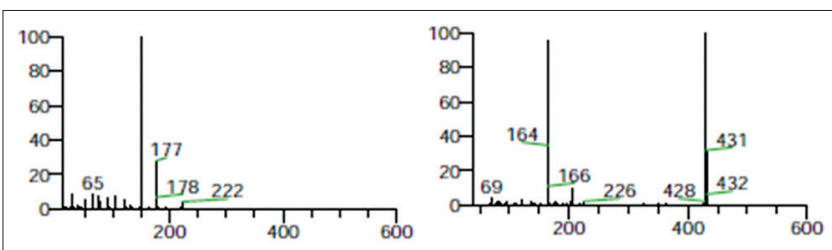

Diethyl phthalate

Vitamin E
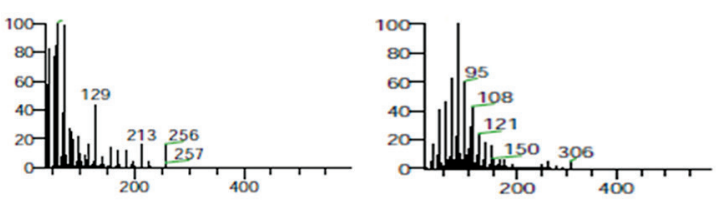

n-hexadecanoic acid

$9,12,15$ octadecatrienoic acid
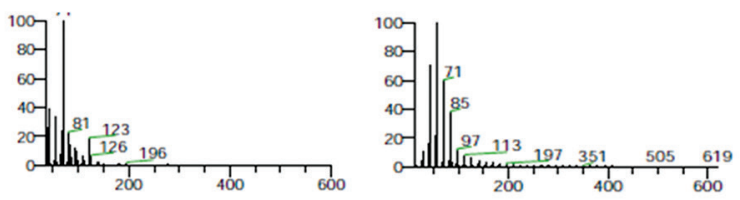

Phytol

Tetratetracontane
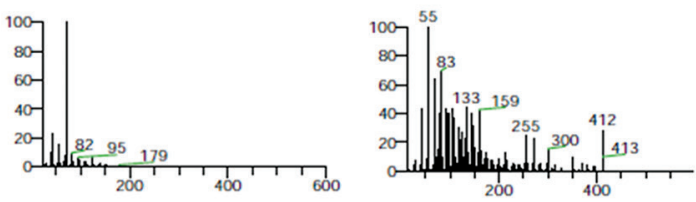

Isophytol

Stigmasterol

Fig. 2: Mass spectrum of identified compounds

$\mathrm{eV}$. The range of the obscure segment was contrasted with the range of standard components put away in the NIST library. Helium acted as a carrier with a gas pressure of $99.999 \%$ and a flow rate of $1.0 \mathrm{ml} / \mathrm{min}$ and electronic pressure control. The sample was added automatically.

\section{Identification of compounds}

The elucidation of GC-MS mass range was made utilizing the National Institute of Standards and Technology (NIST) database, which has in excess of 62,000 models. The range of the obscure segment was contrasted with the range of standard components put away in the NIST library. The name, molecular weight, and structure of the components of the test materials have been established [11].

\section{RESULTS AND DISCUSSION}

GC-MS is the ideal method used for the resolution of volatile compounds. This technique has been the frequently used methods for examining plant samples. In general, GC-MS analysis provides the idea about the chemical structure, molecular formula, and idea about the functional group present in the compound [12].

The GC-MS results of an ethanol extract of $B$. oleracea reveal the appearance of a number of bioactive compounds. The chromatogram of ethanol extracted from B. oleracea is shown in Fig. 1. The most common compounds in the ethanol extract of B. oleracea are diethyl phthalate, 9, 12, 15 octadecatrienoic acid, pentadecanoic acid, Vitamin E, stigmasterol, phytol, isophytol, and tetratetracontane. The phytochemical composition of the ethanol extract of $B$. oleracea with compound name, molecular formula, molecular structure, retention time, and peak area was shown in Table 1, and its biological activity with its structure was given in Table 2 .

Diethyl phthalate was detected at the retention time of 14.88 with its peak area of $78 \%$ and the compound was revealed to possess antifungal and antimicrobial activity. Olawale et al. stated the existence of this compound in Pycnanthus angolensis and proved its antibacterial activity against Escherichia coli [13].

Jagadeeswari et al. reported the documentation of the compound n-hexadecanoic acid in Aristolochia krysagathra. n-hexadecanoic acid has pharmacological activities such as antimicrobial, antioxidant, hypocholesterolemic, antiarthritic, and anti-inflammatory [14]. Phytol was identified at the retention time of 20.29 with the peak area of $2.40 \%$. de Freitas et al., 2013, demonstrated the antinociceptive activity associated with phytol antioxidant activity by in vitro methods [15]. The mass spectrum of different compounds is shown in Fig. 2.

It is well known that isophytol has an antioxidant property and has been identified at a retention time of 20.29 with a peak area of $2.40 \%$ [16]. Vitamin E is a significant vitamin for the human immune system that is naturally present in some food products and can also be obtained in the diet of a supplement capsule. It belongs to a class of compounds that include tocopherol and tocotrienols. Vitamin E includes an antioxidant, antidiabetic, anti-inflammatory, and antiaging process [17]. 9,12,15 octadecatrienoic acid was identified at a retention time of 20.81 with a peak area of $11.08 \%$. It includes anti-inflammatory, 
Table 1: The phytochemical composition of ethanolic extract of Brassica oleracea with the compound name, its molecular formula, molecular structure, retention time, and peak area

\begin{tabular}{|c|c|c|c|c|c|}
\hline S. No & RT & Compound name & Molecular formula & Molecular weight & Peak area $\%$ \\
\hline 1 & 14.88 & Diethyl phthalate & $\mathrm{C}_{12} \mathrm{H}_{14} \mathrm{O}_{4}$ & 222 & 1.78 \\
\hline 2 & 18.70 & Palmitoleic acid & $\mathrm{C}_{16} \mathrm{H}_{30} \mathrm{O}_{2}$ & 254 & 2.09 \\
\hline 3 & 18.70 & Oxacyloheptadecan-2-one & $\mathrm{C}_{16} \mathrm{H}_{30} \mathrm{O}_{2}$ & 254 & 2.09 \\
\hline 4 & 18.70 & 9-Hexadecenoic acid & $\mathrm{C}_{16}^{10} \mathrm{H}_{30}^{30} \mathrm{O}_{2}^{2}$ & 254 & 2.09 \\
\hline 5 & 18.93 & n-Hexadecanoic acid & $\mathrm{C}_{16} \mathrm{H}_{32} \mathrm{O}_{2}$ & 256 & 12.99 \\
\hline 6 & 18.70 & Erucic acid & $\mathrm{C}_{22} \mathrm{H}_{42} \mathrm{O}_{2}$ & 338 & 2.09 \\
\hline 7 & 19.18 & Hexadecanoic acid, Ethyl ester & $\mathrm{C}_{18}^{2 .} \mathrm{H}_{36} \mathrm{O}_{2}$ & 284 & 4.51 \\
\hline 9 & 19.57 & Heptadecanoic acid & $\mathrm{C}_{19} \mathrm{H}_{38} \mathrm{O}_{2}$ & 298 & 4.51 \\
\hline 10 & 20.29 & Phytol & $\mathrm{C}_{20} \mathrm{H}_{40} \mathrm{O}$ & 296 & 2.40 \\
\hline 11 & 20.29 & Isophytol & $\mathrm{C}_{20} \mathrm{H}_{40} \mathrm{O}$ & 296 & 2.40 \\
\hline 12 & 20.81 & $9,12,15$ Octadecatrienoic acid, ethyl ester & $\mathrm{C}_{20} \mathrm{H}_{34} \mathrm{O}_{2}$ & 306 & 11.08 \\
\hline 13 & 23.87 & bis (2-ethylhexyl) phthalate & $\mathrm{C}_{24} \mathrm{H}_{38} \mathrm{O}_{4}$ & 390 & 10.67 \\
\hline 14 & 25.13 & Octadecane, 1-chloro- & $\mathrm{C}_{18} \mathrm{H}_{37} \mathrm{Cl}$ & 288 & 1.81 \\
\hline 15 & 26.57. & Tetratetracontane & $\mathrm{C}_{44} \mathrm{H}_{90}$ & 618 & 2.15 \\
\hline 16 & 28.28 & Vitamin E & $\mathrm{C}_{29} \mathrm{H}_{50} \mathrm{O}_{2}$ & 430 & 3.38 \\
\hline 18 & 29.26 & Cholesterol, 7-Oxо- & $\mathrm{C}_{27} \mathrm{H}_{44} \mathrm{O}_{2}$ & 400 & 4.10 \\
\hline 19 & 29.51 & Stigmasterol & $\mathrm{C}_{29}^{24} \mathrm{H}_{48}^{44} \mathrm{O}^{2}$ & 412 & 2.09 \\
\hline 20 & 33.32 & Methoprene & $\mathrm{C}_{19}^{29} \mathrm{H}_{34}^{46} \mathrm{O}_{3}$ & 310 & 2.03 \\
\hline 21 & 33.32 & Dodecane, 1,12dibromo & $\mathrm{C}_{12} \mathrm{H}_{24} \mathrm{Br}_{2}$ & 326 & 2.03 \\
\hline
\end{tabular}

Table 2: Bioactivity of phytocomponents with its structure identified in the ethanol extract of Brassica oleracea by GC-MS

\begin{tabular}{|c|c|c|c|}
\hline S. No & Name of the compound & Structure & Biological activity \\
\hline 1. & Diethyl phthalate & & Antimicrobial activity, antifungal activity \\
\hline 2. & Palmitoleic acid & & Not intended for therapeutic purposes \\
\hline 3. & Oxacyloheptadecan-2-one & & Not intended for therapeutic uses \\
\hline 4. & n-Hexadecanoic acid & & $\begin{array}{l}\text { Antioxidant, antimicrobial, hypocholesterolemic, } \\
\text { antiarthritic, and anti-inflammatory activities }\end{array}$ \\
\hline 5. & Methoprene & & Not intended for therapeutic uses \\
\hline 6. & Phytol & & Antimicrobial, anticancer, diuretic, anti-inflammatory \\
\hline 7. & Isophytol & & Antioxidant activity \\
\hline 8. & Vitamin E & & $\begin{array}{l}\text { Antiageing, analgesic, antidiabetic, anti-inflammatory, } \\
\text { antioxidant, antidermatitic, antileukemic, antitumor, } \\
\text { anticancer }\end{array}$ \\
\hline 9. & $\begin{array}{l}\text { 9,12,15 Octadecatrienoic } \\
\text { acid, Ethyl ester (Z, Z, Z) }\end{array}$ & & $\begin{array}{l}\text { Anti-inflammatory, hypocholesterolemic, cancer } \\
\text { preventive, hepatoprotective, antibacterial, antiarthritic, } \\
\text { and anticoronary activities }\end{array}$ \\
\hline $\begin{array}{l}10 . \\
11 .\end{array}$ & $\begin{array}{l}\text { Octadecane, 1-chloro- } \\
\text { Tetratetracontane }\end{array}$ & & $\begin{array}{l}\text { Not intended for therapeutic purposes } \\
\text { Antioxidant and cytoprotective activities }\end{array}$ \\
\hline 12. & Stigmasterol & & $\begin{array}{l}\text { Antiosteoarthritic, antihypercholestrolemic, } \\
\text { antitumor, hypoglycemic, antimutagenic, antioxidant, } \\
\text { anti-inflammatory activities }\end{array}$ \\
\hline
\end{tabular}

GC-MS: Gas chromatography-mass spectroscopy 
anticancer and hypocholesterolemic, hepatoprotective, antibacterial, antiarthritic, and anticoronary activities. Sermakkani et al. described the occurrence of this compound in the Cassia italica leaf and reported its pharmacological activity [18].

Tetratetracontane was identified at a retention time of 25.13 with a peak area of $2.15 \%$. Mallick et al. identified this compound by the highperformance thin-layer chromatography technique and represents the antioxidant and cytoprotective properties [19]. Stigmasterol is well known by its other name called Wulzen anti-stiffness factor is a type of unsaturated plant sterols. Stigmasterol was reported by Gabay. 0 for its anti-osteoarthritic activity. Stigmasterol includes antimutagen antioxidant and anti-inflammatory and also plays a role in regulating cholesterol biosynthesis by inhibiting $\Delta 24$ reductase [20]. Nowadays, developing the drugs with improved tolerance and/or specificity is an imperative goal for the drug industry, which can be achieved from herbal plants [21].

\section{CONCLUSION}

The GC-MS result of the ethanol extract of $B$. oleracea exaggerates the manifestation of more than 20 phytocompounds. It explores the persistence of numerous bioactive constituents which have the ability to act as a prospective substance of drugs in the pharmaceutical industry. This proves that $B$. oleracea can be utilized to treat the various ailments and is of pharmaceutical significance. However, further research is required to elute the novel bioactive compounds.

\section{AUTHOR'S CONTRIBUTION}

No author's contribution.

\section{CONFLICTS OF INTEREST}

There are no conflicts of interest.

\section{REFERENCES}

1. Vasanthi HR, ShriShriMal N, Das DK. Phytochemicals from plants to combat cardiovascular disease. Curr Med Chem 2012;19:2242-51.

2. Ravishankar B, Shukla VJ. Indian systems of medicine: A brief profile. Afr J Tradit Complement Altern Med 2007;4:319-37.

3. Varadharaj V, Muniyappan J. Phytochemical and phytotherapeutic properties of Celosia species-a review. Int J Pharm Pharm Res 2017:9:820-5

4. Gordon DM. Geographical structure and host specificity in bacteria and the implications for tracing the source of coliform contamination.
Microbiology 2001;147:1079-85

5. Vanitha J. Betaine supplementation for various clinical disorders. Asian J Pharm Clin Res 2017;10:27-31

6. Vanitha V, Jayalakshmi M, Amudha P, Pushpabharathi N. Assesment of minerals from shell waste of Penaeus indicus. Int J Res Pharm Sci 2017;8:194-7.

7. Webster M. Broccoli. Merriam-Webster's Collegiate Dictionary. 11 $1^{\text {th }}$ ed. America: ???; 2014:156.

8. Waltenberg LW. Inhibition of carcinogenesis by non-nutrientconstituents of the diet. In: Food and Cancer Prevention. Chemicaland Biological Aspects. London: The Royal Society of Chemistry; 1993. p. 12-24.

9. Xue M, Qian Q, Adaikalakoteswari A, Rabbani N, Babaei-Jadidi R, Thornalley PJ, et al. Activation of NF-E2-related factor-2 reverses biochemical dysfunction of endothelial cells induced by hyperglycemia linked to vascular disease. Diabetes 2008;57:2809-17.

10. Krishnakumari ST, Muthukumarasamy S, Mohan VR. GC-MS analysis of ethanol extract of Sarcostemma secamone(L) Bennet (Asclepiadaceae). Sci Res Rep 2012;2:187-91.

11. Mathi P, Nikhil K, Das S, Roy P, Bokka VR, Botlagunta M. Evaluation of in vitro anticancer activity and Gc-Ms analysis from leaf Sophora interrupta bedd. Int J Pharm Pharm Sci 2015;7:303-8.

12. Khumukcham N, Ajungla T, Singh CB. GCMS based metabolic profiling of essential oil of Citrus macroptera montruz. Leaves and peel, assessment of in vitro antioxidant and anti-inflammatory activity. Int J Pharm Pharm Sci 2017;9:107-14.

13. Oladimeji $\mathrm{OH}$, Attih EE, Onu NO. Ethyl linalool and diethyl phthalate from pycnanthus angolensis (Welw.) warb. Eur Chem Bull 2017;6:76-8.

14. Jegadeeswari P, Nishanthini A, Muthukumarasamy S, Mohan VR. GC-MS Analysis of bioactive components of Aristolochia krysagathra (Aristolochiaceae). J Curr Chem Pharm Sci 2012;2:226-32.

15. de Freitas RM, de Menezes Patrício Santos CC, Salvadori MS, Mota VG, Costa LM, de Almeida AA, et al. Antinociceptive and antioxidant activities of phytol in vivo and in vitro models. Neurosci J 2013;2013:Article ID 949452.

16. Dubois RN, Abramson SB, Crofford L, Gupta RA, Simon LS, Van De Putte LB, et al. Cyclooxygenase in biology and disease. FASEB J 1998;12:1063-73.

17. Dr. Duke's Phytochemical and Ethnobotanical Databases. Available from: http://www.ars-grin.gov/duke/. [Last accessed on 2012 Aug 10].

18. Sermakkani M, Thangapandian V. GC-MS analysis of Cassia italica leaf methanol extract. Asian J Pharm Clin Res 2012;5:90-4.

19. Mallick SS, Dighe VV. Detection and estimation of alpha-amyrin, beta-sitosterol, lupeol and n-tricontane in two medicinal plants by high performance thin layer chromatography. Adv Chem 2014;2014:Article ID 143948.

20. Kaur N, Chaudhary J, Jain A, Kishore L. Stigmasterol: A comprehensive review.Int J Pharm Sci Res 2011;2:2259-65.

21. Casucci I, Provenzani A, Polidori P. Evaluation of treatment of invasive fungal infections. J Pharmacol Pharmacother 2014;5:47-52. 